\title{
Patchwork and PR: Seminole-Constructed Public Image
}

\section{Cynthia Kasee}

Florida Seminoles represent a unique "response culture" among Southeastern Native Americans. An amalgamation of tribes, their history has been marked by their adaptability in the face of massive cultural change. Today the Seminoles are a major force in Florida's economy and politics. The public face they present has largely been of their own making throughout their history, and now it is more consciously so.

Indians lacked certain or all aspects of white civilization and could be viewed as bad or good depending upon the observer's feelings about his own society and the use to which he wanted to put the image. In line with this possibility, commentators upon the history of white imagery of the Indian have found two fundamental but contradictory conceptions of Indian culture (Berkhofer 1978:27-28).

To even the most casual of observers, it is apparent that the cultures of Native America are rich and diverse, adapted as they are to ecosystem, history, and contact with others, to 


\section{Ethnic Studies Review Volume 23}

name but a few catalysts. It would be difficult to point out another indigenous group whose culture has been as creative in its response to these elements as has the Florida Seminole. Throughout much of its existence as a culture (separate from its many ancestral components) the public image of the Seminole has been structured by outsiders though. It has largely been in the 20th century, and as a response to tourism, that the Seminole of Florida have consciously constructed the public image they wish to project.

\section{History}

Unique among indigenous Americans, the Seminole and their kin, the Miccosukee, are a true "response culture." That is, although they draw genetically from ancestors representing nearly a hundred tribes, what is today recognized as "Seminole" (as a lifeway) is the result of numerous adaptations made to changing environments, both physical and social. Although they descend from many people not native to the Florida peninsula, they are distinctly a culture born in this subtropical land.

The encroachment of Euro-Americans in the Southeast in the colonial period increased tensions with the Natives living there. In the coastal marshlands of the Carolinas and Georgia small groups of people speaking related Muscogulgee languages were displaced, died from war and contagion, and were generally disrupted culturally. These groups, including such people as the Guale, Yamassee, Yuchi, and members of the "Creek Confederacy," responded in a variety of ways. Some resisted militarily, while others withdrew west, hoping to avoid the whites while still surviving their onslaught (Kersey 1975; Kersey and Bannan 1995, 193-212).

As the British colonies transformed into the United States wholesale settlement in the trans-Appalachians began. With the Mississippi River running through the heart of the land of the western "Creeks" they already had had prolonged exposure to the French, Spanish, and British, but the Americans were different; the Americans wanted their land and wanted the Natives "removed" to a far-off land west of the great river. When the Americans fought their English cousins in 1812, they sought alliance with the Muscogeans and the Cherokee. The 
latter accepted the call, while most of the former either sided with the British or tried to remain neutral. The American victory would prove costly to the Natives of both sides (Covington 1993; Garbarino 1986).

This fight between the whites had two enduring negative effects on the Muscogee: it catapulted the "hero" of the Battle of New Orleans, Andrew Jackson, into the national spotlight from where he would go on to enforce Indian "removal" with his election to the presidency; it also drove a wedge into the "Creek Confederacy," resulting in a long civil war, the "Red Stick War." While militant "red sticks" fought pacifist "white sticks," a third faction of the Muscogee simply walked away from the conflict. This third group, seeking distance from both their kin and the Americans, crossed the international border into Florida. Although Florida was divided into British and Spanish sectors, Spanish influence was still present in British West Florida. In Spanish, those Indians who "ran" away from the Red Stick War were "cimarrones," runaways. Without a phonic equivalent of the Spanish double-r sound, the Natives approximated the term as best they could, finally settling on "Siminoli," and later "Seminole" (Garbarino 1986; Covington 1993; Kersey and Bannan 1995).

Seminole recalcitrance to engage in regular contact with whites was therefore a result of a long history of being on the losing end of the proposition when Euro-Americans entered an area. The West Florida Seminole moved east, out of the panhandle, toward the more sparsely populated peninsula and northern savannah. Along the way they encountered the small remnants of Florida's truly indigenous people, groups such as the Apalachee, Timucuan, Calusa, and others. Particularly on the northern savannah (present day Alachua County and its environs), they also met up with "cousins," people like the Oconee and remnant Yamassee, themselves fleeing the Macon Plateau in advance of massive white settlement. Intermarrying, in both the literal and cultural sense, the West Florida Seminole incorporated the last of Florida's first inhabitants, as well as their relatives, frequently called "Miccosukee," a reference to their major settlement near present day Gainesville. Add to the mix African and African-American slaves escaping across the international line into Spanish 


\section{Ethnic Studies Review Volume 23}

Florida, and the resulting cultural amalgam became the "Florida Seminole" (Covington 1993; Kersey 1996; Kersey 1975; West 1998).

From this nativity in the latter days of the 17th century, through the First (1817-1818), Second (1835-1842), and Third (1855-1858) Seminole Wars, this uniquely Floridian group was viewed largely through the American lens. They were portrayed as a danger to those (whites) brave enough to emigrate to Florida as well as an economic threat to the slave-based Southern society lurking just north of Florida (indeed, even after the U.S. acquired Florida, slave lore continued to point the way to a safe haven among the Seminole and Miccosukee in Florida).

The key event in the creation of this image of the Seminole as a dangerous, savage people was the onset of the Second Seminole War. In 1830 Congress had passed the Indian Removal Act, and it meant that Florida Native Americans were to be compelled to leave the state if they would not voluntarily leave. Already in the preceding decades the Seminole had made treaties and land sessions hoping to be left alone in the land they now considered home. Why, they reasoned, could the Americans not leave them alone in the state's swampy interior, a place so remote and hostile to white sensibilities? Of course the answer was that the fever of Manifest Destiny could countenance no holdouts, for if the Florida Indians stayed, surely others would protest and resist their own exile.

When a party of Seminole agreed to travel to "Indian Territory" to view the place, they believed they were being dealt with honestly. At Fort Gibson, Arkansas, they were tricked into signing a paper, having been told it was a voucher to get the federal government to cover their expenses; it was not. It was a "removal treaty." Upon their return to Florida, crestfallen and fearful for their people's future, the treaty party related the latest American subterfuge. Over the next three years, the U.S. tried to force the Seminole into negotiations for their exile, a mostly unsuccessful business, since the Seminole could rarely be coaxed from their inaccessible homes. When finally a parlay was arranged, the Americans encountered the first Seminole "media star," Osceola (Covington 1993; Garbarino 1986; Kersey 1996, 1975). 
Even though the Seminole were a people whose culture was in a near constant state of flux in these days, they still retained many traditions from their ancestral tribes. Among these was a very specific method for determining chieftainships, a system based upon wisdom, age, and often war honors. As this group parlayed with the Americans at Payne's Prairie (Alachua County), a young man decidedly not recognized as a chief of any type made a statement that would thrust him into the national psyche, creating Americans' first clear image of the Seminole Indians. His name was "Asi-Yahola," "Black Drink Crier," a name Americans transliterated as "Osceola." Osceola was that most unwieldy of national figures; he was at once seen as the embodiment of the implacably cruel and dangerous Indian savage and conversely as a hale enemy well met, one who was paid a measure of respect (Berkhofer 1978; Kersey 1996, 1989, 1975).

What had so indelibly burnt Osceola into the American sensibility? When faced with the confirming document of removal, the treaty which would doom his people to a long walk to cultural oblivion, he had stabbed his hunting knife into the parchment declaring "This is the only treaty I will ever make with the white man," or dramatic words to that effect (Covington 1993:73). Today we can only imagine the effect this had when presented in the tabloids of the North and East, perhaps analogous to such famous phrases as FDR's post-Pearl Harbor speech referring to the attack as "a day that will live in infamy." Osceola's words (or those attributed to him through a translator) were as clear a declaration of war but a declaration of a war against America. It must have colored the way in which Americans viewed the Seminole image.

A scant two decades before (1818) Creek and Seminole agent and attorney Alexander Arbuthnot had depicted his "clients" in the commonly bucolic "Noble Savage" mold:

These men are children of nature; leave them in their forests to till their fields and hunt the stag, and graze their cattle, their ideas will extend no further;

(Arbuthnot's journal cited in Covington 1993, 40)

By Osceola's 1835 call to arms, few Americans held such an innocuous image of the Seminole. They believed the previous years had ushered in a phase in which the Seminole had 


\section{Ethnic Studies Review Volume 23}

grown lazy on government largesse. Indeed in 1828 Florida territorial governor William Duval (for whom the county is named) called them "wanton and insolent" (Covington 1993:61), a curious choice of words given that the government rations were actually payment for Seminole lands. Regardless, America in 1835 was ready to cast the Seminoles, supposedly under the unanimously approved war leadership of Osceola, as ingrates, bloodthirsty and prepared to engage in the wholesale slaughter of blameless settlers (Covington 1993; Kersey 1975).

As with most media-created phenomena, Osceola couldn't live up to the indestructability Americans believed he possessed. Through fraud, he was enticed to his own capture from whence he and his kin (not charged with any crime) were sent to the military prison at Ft. Moultrie, S.C. From what media portrayed then and what U.S. history books have perpetuated, America learned that the fearsome enemy, both hated and admired, died there, unable to accept the shame of defeat and imprisonment. Most Florida schoolchildren are still not told that Osceola died from an untreated case of tonsilitis, an act of intentional malpractice. The physician, Dr. Weedon, was the brother-in-law of the late Wiley Thompson, a military commander Osceola had killed during the Second Seminole War. The Army didn't view as a conflict-of-interest assigning this grieving relative to attend Osceola, and Weedon's studied indifference cost Osceola his life. The final indignity, that Weedon decapitated the Seminole warrior and kept his head as a grotesque souvenir, is likewise rarely a part of official U.S. history books (Kersey 1975).

Though another "Seminole war" lay ahead for Florida's Natives, by 1842 , the common public image was that the Seminole were no longer dangerous. True, a few had been removed to Indian Territory, many had been killed, and some had withdrawn into the Everglades, beyond the reach of even the most ardent army. While America began to turn its attention to the growing chasm between pro- and anti-slavery factions, stalwart Seminoles in Florida were attempting to become as invisible as possible to evade removal. It was then with some surprise that America woke up to another Seminole war in 1855. In the previous decade Governor William Moseley had 
petitioned President Polk, "The Indians must be removed peacefully if they can, forcibly if they must" (Covington 1993:112). Indeed, the Florida public had been kept in foment, if such portrayals as the following excerpt from the St. Augustine Ancient City (newspaper) of June 10, 1852, is representative:

Last fall, one thousand five hundred troops were sent here against Indians to coax one hundred thirty assassins to give up five of their number and used two months to deliberate. Nine months time was wasted. Millions of dollars [were used] to bribe $70-80$ old men, women and children and three murderers out of Florida. The murderers are set free in the west. We can expect nothing from a Federal government committed to peaceful removal and [look] only to our state legislature. Florida Indians should be outlawed and [a] reward [offered] of $\$ 1,000$ for [a] man dead or alive and $\$ 500$ for [a] live woman and child. Thus, people could still hunt them...soldiers not worth $\$ 7$ per month. We need thousands of hunters, (Covington, 1993, 121-2).

At this juncture a peculiar dichotomy developed. Outside Florida the remembrance of Osceola as a respectable (but doomed) warrior transformed public opinion toward the Seminole. As if a gift wafting from his grave Osceola's national image had bequeathed to the Seminole an intangible romance. Patsy West (1998) refers to it as a commodity called "unconquered" $(26,31)$. Of course within the state the fact that Seminoles remained "at large" (as Floridians viewed it, seeing the Indians as federal fugitives) was not cast in the same romantic light. The Seminoles were competitors for land, water, game, just as later they would be competitors for tourist and gambling dollars. (Kersey 1996, 1970, 1975; West 1998).

The Third Seminole War was almost a non-event, at least as seen by the national audience. In fact with the Civil War, Reconstruction, and Manifest Destiny-driven westward migration the remaining years of the 19th century saw little public attention paid to the Florida Seminole (although the role of the Oklahoma Seminole in the Civil War as supporters of the Confederacy garnered them much negative publicity, and they 
"paid" land reparations). In fact it would take a war of another kind to rivet America's attention on the Florida Seminoles again. This war would involve the Florida Land Boom and the battle for tourist dollars (West 1998, 1981, 1987, 1996).

During America's Gilded Age, robber barons of industry, men who were fabulously wealthy in an era before income taxes, were in search of new playgrounds. Their social seasons in residence in New York City or Newport, RI, could be chilly affairs, and they set their sights on warmer climes. With the initiative of railroad magnates Henry Flagler and Henry Plant, the east and west coasts of Florida (respectively) were coming under rail lines, and resorts were being built at various points of disembarkation. Furthest south along the east coast was the golden triangle of Palm Beach/Miami/Coral Gables. Soon it became de rigeur to "winter in Miami," and a riot of real estate speculation ensued. In the early 1920s, years before the fall of the stock market, but in the post-WWI economic boom,the growing allure of Florida drew two types of visitors: wealthy socialites who bought homes and modestly well-off folks who merely vacationed in the Sunshine State. It was this second group that would prove crucial to the development of a Seminole constructed public image.

Gold Coast millionaires might occasionally venture into the nascent tourist venues of Greater Miami, but it was the middle class visitors who flocked to such innovative attractions as Coppinger's Tropical Gardens and Musa Isle. These sites combined the exotic foliage of South Florida with the equally exotic fauna, including tropical birds, snakes, and alligators-oh, and Seminoles. By now used to viewing Indians as conquered museum pieces, tourists saw no irony in grouping these indigenous humans with zoo fare (West 1998, 1981, 1987, 1996).

It was the bane of the existence of "friends" of the Indians that these tourist "camps" operated. Indian agents, school teachers, missionaries, social workers, politicians, and wealthy matrons who took on the "saving" of the Indians as a hobby, all deplored Coppinger's, Musa Isle, and a host of other such attractions. As they saw it, Seminoles were lured to these places with promises of easy money, little hard work, and free lodging. None of the preceding elements were viewed as pre- 
cursors to Seminoles becoming "civilized," adopting the Protestant work ethic of much of America. In public venues, these concerned parties reverted to portraying the Seminole as children of nature again, guileless children about to be exploited and ruined for purposes of civilizing (West 1998, 1981, 1987, 1996).

Curiously it was just this advent of tourist attractions that led the way to the Seminole seizing the reins of crafting their public persona. Largely due to the research efforts of Patsy West, this era is now seen as a very positive development in Seminole sovereignty. The operators of places like Coppinger's and Musa Isle saw the Seminoles as equals although also as employees. They generally paid them fairly for their residence at the attractions and were keen judges of who to approach among the Seminole to act as "headmen." They evidenced a willingness to incorporate Seminole cultural aspects in both the commercial depictions and the behind-thescenes relationships with their "workers." Traditional religious rites, tribal jurisprudence, and historic alliances and divisions were taken in stride (Downs 1981; West 1998).

Not surprisingly then the attraction operators were also quick to see that, while culturally traditional, the tourist camp Seminole were innovators. These businessmen did not stoop to depicting their co-workers as "children of nature" nor as throwbacks to an earlier age. The tourist camp Seminoles liked their phonographs, occasional shopping trips to Miami department stores, and not a small measure of socializing with nonIndians. They became vocal opponents of the so-called "friends" of the Indians, pointing out that the tourist camp workers saw themselves as paid professional actors, not seeing an ounce of degradation in the transaction. They were savvy in recognizing that for some of the so-called "do-gooders" at least trying to keep the Seminole "innocent" and isolated was a pretty self-interested matter. Of course they readily admitted the self-interest they indulged in, raking in tourist dollars, but also sharing the bounty with the Indians (Downs 1981; West 1998, 1981, 1987, 1996).

While some of these tourist attraction purveyors may have been but a notch above snake oil salesmen, they also didn't harbor prejudice toward Seminoles "making it" in the tourist 


\section{Ethnic Studies Review Volume 23}

trade. An early example is that of Willie Willie, who purchased Musa Isle, becoming the first Seminole to own a tourist camp, a distinction he held singularly until some "Tamiami Trail Seminoles" opened small roadside attractions in the 1930s. Willie became a millionaire (in 1920s money!), married a white woman, bought a luxury car, and became quite a clothes horse, even doing some modeling of fine menswear for Burdine's department store in Miami. While some of the more stalwart Everglades traditionalists may have seen him as a "sell-out," he was a role model for the tourist camp Indians. He cut an interesting public figure as well, this in a Miami with strict segregationist laws and mores; he was seated at fine restaurants and feted at mansions, his white wife by his side (West 1998).

Willie Willie is the first example of a Seminole consciously honing a public persona in the 20th century, at least "public" in the sense of projecting a crafted image to non-Indians. Many tourist camp Seminoles followed suit, with perhaps the next most accomplished image-maker being Jack Tiger Tail. Tiger Tail was a camp performer and an alligator wrestling, a virtual prerequisite for tourist fame among Seminole men. He was so compelling a figure that his likeness was used in the official seal of the new City of Hialeah, a likeness that was then adopted for a larger-than-life billboard advertisement for the town. He was mentioned in newspaper and magazine stories, photographed by the press and tourists alike, and made a local celebrity of sorts. In fact when Jack Tiger Tail came to an inglorious end, executed under tribal jurisdiction for adultery, the public wasn't prepared to hear ill of their "star." A white man was tried for the murder, a man known for illegally purchasing (federally protected) migratory bird plumes from the Seminoles, often paying them in rotgut liquor. Adroit Seminole men participated in the trial, giving eloquent testimony but never mentioning that everyone in the village knew who had killed Tiger Tail and why. It would take decades before white Miamians would hear the truth, and even then they resented the fact that the pristine image of Tiger Tail had been sullied with mundane facts (West 1998).

Willie Willie also met a sad end. Swindled out of ownership of Musa Isle, he died impoverished of tuberculosis. He was not 
so publicly mourned though. For one matter he had long been out of the public eye when he succumbed to t.b.; for another his flaunting of social convention for people of color may have been just a bit too much for Miamians to embrace him as they had Jack Tiger Tail. After the era of Willie and Tiger Tail, it would be five decades before another Seminole would take center stage, actively creating a public image, both for himself and for his people (Downs 1981; West 1998, 1981, 1987, 1996).

From the Great Depression through the post-WWII era, tourist camps dwindled. They were largely seasonal attractions, and with poverty and gasoline rationing there were simply not enough tourists to make the camps going concerns. By the 1950s, though, America was again yielding the treasures of a boom economy, and affordable cars made a Florida vacation an attainable dream for the middle-class. The tourist attractions opened their doors again, joined as they were by many newer, smaller roadside Seminole camps on Tamiami Trail and Alligator Alley. Again Seminoles were in demand as paid performers, and this is precisely how they saw themselves. While government officials, teachers, and missionaries still bemoaned the practice as demeaning, and while many, if not most, of the paying tourists thought the Seminoles lived in abject poverty virtually "begging" for a living, the Indians themselves were proud of their efforts and pleased for the opportunity. A camp family might make enough money in a few months' worth of accepting tips for photos or alligator wrestling (as well as the sale of their crafts) to see them through the off-season comfortably. Nothing the Bureau of Indian Affairs had to offer was that attractive; besides, the making of crafts and the "playacting" of their daily chores for tourists' eyes was a way of keeping these cultural elements alive, while still introducing them to the market economy (Downs 1981; West 1998, 1996; Kersey and Bannan 1995; Kersey 1996, 1989, 1970).

When Patsy West pulled together twenty years of research for her 1998 work, The Enduring Seminoles: From Alligator Wrestling to Ecotourism, she noted that she found not one Seminole or Miccosukee family that hadn't had family members involved in the tourist camps whether the attractions were owned by non-Indians or by individual Seminole families or the 


\section{Ethnic Studies Review Volume 23}

tribe as a whole (the Okalee Indian Village) (xiv-xvi). Likewise she found no one who wholly dismissed the experience as negative; indeed, many were quite nostalgic about their days as "performers" (xv).

While tourism is Florida's major industry, it alone cannot be expected to support a modern Native nation, nor can it provide the social or economic impetus to diversify and remain economically sound. Therefore tribal council members in the post recognition phase (after 1957 for the Seminole, 1961 for the Miccosukee) were always on the lookout for economic opportunity, carefully cultivating the tribe's public image to aid in this effort. They emphasized the Seminole quest for formal education and the tax advantages for companies that set up shop on the federal reservations. Sadly most of these ventures failed to pay off for the Indians, as industries wouldn't live up to their promises to hire Seminoles for many of the jobs in these plants. When the reality of the transportation problems faced in the Everglades dawned on these businesses, most left. Still the Seminoles persisted in presenting themselves to industry as attentive, skilled workers, tax-break landlords, and brokers of a unique international trade status.

Truthful as this depiction may be, it failed to make the Seminole Tribe of Florida, Inc. an attractive proposition to big business (the tribe is governed by a council, but business is conducted by a corporation!) The idea had long been held that the tribe needed to make its own "big business," but how to go about that seemed to elude them, that is, until the political tenure of a man sometimes called "the second Osceola," James Billie.

Chairman Billie is nothing if not a flamboyant public persona. It's rare to see a newspaper or magazine article about him that doesn't append the term "flamboyant" to his name like a formal title. Floridians, Native and non-Native, have had to choose sides about this dynamo, as there appears to be no middle ground; people either love or hate him. He is well aware of this dichotomy and equally well aware that his ability to rivet media attention is what has "bought" a public stage for his people. He makes no apologies for his high profile and takes no pains to hide the "rougher" portions of the image.

Born in a tourist camp, James Billie seemed destined to be 
a Seminole showman of some sort. He was of mixed ancestry, and grew up in the mixed culture milieu of a tourist attraction. After early years that included stints in Vietnam and as an alligator wrestler, Billie finally came to the fore in Seminole politics. Beginning his first term as Tribal Chairman in 1978, he remains in that job in 2001 , evidence that his people approve of the work he has done (West 1998).

Although his predecessor, Chairman Tommie, actually initiated the modern era of Seminole economics with his efforts to enter into a pact with casino managers to start a Seminole gaming hall, it was Billie who followed through on the dormant pact. He also "tribalized" the ownership of the first Seminole smokeshops in Florida, fighting federal and state court cases along the way. The effect of these lawsuits and federal cases was contemporary High Court re-approval of early 19th century decisions that Indian nations retained aboriginal rights and sovereignty. In the midst of these high profile legal battles, Chairman James Billie became a national figure, and the public image of the Seminoles as a fully modern, progressive, corporate-styled tribe was cemented (West 1998).

Gaming is a tricky issue in "Indian Country." Many Natives deplore it, feeling it preys on people's weaknesses and that it runs counter to cultural tradition. Looking back historically, we can see that many, if not most, indigenous nations had forms of gambling and these were accepted, fully-integrated elements of culture. Smokeshops are less controversial, perhaps because it is more readily acknowledged by contemporary Natives that smoking has long been part of indigenous cultures. Still, outside "Indian Country," the Seminoles are seen as consummate purveyors of vice-for-profit, supposedly wealthy pashas of bingo and no-tax cigarettes.

Interestingly for a thorough understanding of this public perception, it must be remembered that Florida is a state without personal income tax. The tax base of Florida consists of Property Tax (which is not paid on federal reservation or trust land or buildings), Sales Tax (which is not collected on smokeshop goods), and Luxury Tax, such as on tourist-related purchases of goods and services (not paid on stays at triballyowned lodgings, purchases from reservation-based restaurants, or from gift shops). Given this information, the Seminole 


\section{Ethnic Studies Review Volume 23}

are re-cast as "villains," again competitors for tourist dollars, much as they were in the 1920s. In much of the Florida press this image of the Seminole as aggressive competitors with unfair business advantage is cultivated, and the controversial Billie's persona is extrapolated as a tribal character. Not a state election year passes without petitions being circulated to restrict Seminole gaming and other sources of revenue, items to be offered as referenda in ignorance of the federal nature of the laws governing the tribe. This rush to "expose" the aggressive, underhanded nature attributed to the Seminole reached its apex in recent events sometimes called the "Fourth Seminole War."

Between December 19 and 21, 1997, the well-respected daily, the St. Petersburg Times ran a three article exposé of the Seminoles. Prior to the series publicity was already brewing about it so contentious were the events surrounding the research and writing of the articles. Drawn into the fray were the principals (the tribe and the newspaper), the Poynter Institute on Ethics in Journalism, the Tampa Bay local "free press" tabloid, The Weekly Planet, the Journalism department of the state's flagship university, and countless media outlets around the state and the nation.

The crux of the controversy appears to have been a preconceived intent by the authors, Brad Goldstein and Jeff Testerman, to find evidence supporting a public supposition of tribal corruption and proof that such avarice was a result of Seminole economics. Strangely the original impetus for the articles had been a plan to look into billing irregularities within the Indian Health Service structure among the Seminole. While such information, if uncovered, would hardly be news in "Indian Country" (whether by dishonest intent or mishandled paperwork), the research quickly took a nefarious turn. In seeking to write an exposé worthy of Woodward and Bernstein, the authors (it was later proven by informant testimony) attempted to coerce a tribal health worker to steal confidential patient records to support their contention. The turn away from journalistic ethics escalated as the story idea shifted to a clandestine effort to prove widespread fraud and nepotism in the tribal government.

Goldstein and Testerman, both hired as free-lance writers 
by the Times for the sole purpose of this series, began a campaign of sending out unsigned, incendiary letters to tribal members. The letters solicited stories of tribal government malfeasance and favoritism but did so couched in the terms of stating dishonesty as a proven fact, goading recipients to confirm these explicitly stated allegations. Word of the letters soon spread outside the Seminole nation, and long before the Times exposé could run other media were printing exposés of the exposé! Copies of the notorious letter were reprinted in the Seminole Tribune, and a flurry of editorials, articles, and "Letters to the Editor" followed. The Tribune clearly took the ethical high road avoiding the hyperbole and sensationalism of Goldstein and Testerman. In a stunning about-face, the St. Petersburg Times announced the writers had been fired and their journalistic methods, if not their ethics, were publicly disavowed.

The Times had little choice by this stage. Copies of the articles (in original form) and research notes, with all identifying information removed, had been forwarded to the Journalism Department of the University of Florida (Gainesville) and the St. Petersburg-based Poynter Institute on Ethics in Journalism. UF's journalism faculty (several of whom were enlisted to review the material) reported on the poor quality of research done as well as the blatantly unethical manner in which information had been solicited from informants. Without knowing the source or intended outlet for the work, they concluded that such would not be tolerated from first-year journalism students.

The Poynter Institute's remarks were equally scathing, deploring the methods and preconceived motives. This analysis was a little more difficult for the Times to accept in the public arena; the Poynter Institute was founded by the Poynter family who owns the Times and who fund the Institute to act as an educational arm and arbiter of journalistic ethics for the unschooled public! Perhaps understandably by the time the December, 1997, articles ran, they had been edited to remove much of the questionable material. By no means did the Seminoles come off as blameless victims in the printed versions. There was still plenty of vilifying of James Billie and references to how economically aggressive the tribe supposedly 


\section{Ethnic Studies Review Volume 23}

is, but all the assumedly litigable material had been excised.

The "Fourth Seminole War" in many ways replayed earlier themes of the constructing of Seminole image. Goldstein and Testerman sought to enlighten naive liberals that the Seminole were no longer "Indian enough" because they were now successful in the market economy. As Office of Indian Affairs applied anthropologist Gene Stirling had decried in his 1936 Report on the Seminole Indians in Florida, "The Seminoles are still too primitive to be in constant contact with a resort city like Miami without it doing them immeasurable harm" (cited in West 1998, 100-101). Perhaps, as Margot Ammidown noted in Florida Anthropologist (1981), the reality was the white man's fear that the Seminoles would learn the game of American economics too well, beating the white man at this game. The opportunities that have presented themselves to the now image-conscious Seminoles are the reward for learning the game and carefully constructing the public image of being a winning team.

\section{Works Cited}

Ammidown, Margot. "The Seminole Tribe, Inc.: Winning and Losing at the White Man's Game." Florida Anthropologist 34 (December 1981):238-42.

Berkhofer, Robert F., Jr. The White Man's Indian. NY: Vintage Books, 1978.

Covington, James W. The Seminoles of Florida. Gainesville: University Presses of Florida, 1993.

Downs, Dorothy. "Coppinger's Tropical Gardens: The First Commercial Indian Village in Florida." Florida Anthropologist 34 (December 1981): 225-31.

Garbarino, Merwyn. Big Cypress: A Changing Seminole Community. Prospect Heights, IL: Waveland Press, 1986.

Kersey, Harry A., Jr. and Helen M. Bannan. "Patchwork and Politics: The Evolving Roles of Florida Seminole Women in the 20th Century" (193-212) in Negotiators of Change: Historical Perspectives on 
Native American Women, (Shoemaker). NY: Routledge, 1995.

Kersey, Harry A., Jr. An Assumption of Sovereignty; Social and Political Transformation among the Florida Seminole, 1953-1979. Lincoln, NE: University of Nebraska, 1996.

The Florida Seminoles and the New Deal, 19331942. Boca Raton, FL: Florida Atlantic University, 1989.

A History of the Seminole and Miccosukee Tribes, 1959-1970. U.S. Dept. of Commerce. Washington DC: National Technical Information Service PB 233052.

Pelts, Plumes, and Hides: White Traders among the Seminole Indians, 1870-1930. Gainesville: University Presses of Florida, 1975.

No Author. Seminole Tribe of Florida 20th Anniversary of Tribal Organization, 1957-1977. Tallahassee: Florida Historical Society, 1977.

Nunez, Theron. "Touristic Studies in Anthropological Perspective", (26574) in Hosts and Guests: The Anthropology of Tourism, 2nd ed. (Smith). Philadelphia: University of Pennsylvania, 1989.

West, Patsy. "Doing the Boats." Seminole Tribune, "Reflections," no.43 (April 6, 1987). Seminole Communications, Seminole Tribe of Florida, Hollywood.

The Enduring Seminoles: From Alligator Wrestling to Ecotourism. Gainesville: University Presses of Florida, 1998.

"i.laponki.: The Florida Seminoles in the 1930s." Native Peoples Magazine 9, no. 3 (Spring):26-33. Phoenix, 1996.

"The Miami Indian Tourist Attraction: A Historic and Analysis of a Transitional Mikasuki Seminole Environment." Florida Anthropologist 34 (December 1981):200-20. 